$\Phi=$ 줄

\title{
Prevalence of traumatized permanent incisors among Yemeni children
}

\author{
Khaled A. AL-Jawfi * \\ Associate Professor of Oral Pathology, Oral Pathology Unit, Department of Biological \& Preventive Sciences, \\ College of Dentistry, University of Science \& Technology, Sana'a, Yemen \\ *Corresponding author E-mail: aljawfi1970@yahoo.com
}

\begin{abstract}
Objective: This study was designed to determine the prevalence and identify the causes of traumatized permanent incisors among Yemeni children.

Patients and Methods: This study was conducted on five hundreds Yemeni children, (250) boys and (250) girls with an age ranged from 8 -12 years. The sample was collected from pediatric dental clinics, College of Dentistry, University of Sciences \& Technology, Sana'a, Yemen.

Results: In the total sample of 500 child, 36 traumatized cases with a prevalence of $7.2 \%$. Regarding to the gender, the prevalence of traumatized cases was found in boys $(9.6 \%)$ more than girls $(4.8 \%)$ with a ratio of $2: 1$. Regarding to location of trauma, the maxillary central incisors were the highest traumatized cases (86.1\%). Regarding to type of trauma, untreated dental fracture was the highest prevalence $(58.3 \%)$ of all traumatized cases for both genders and excluded tooth was the lowest prevalence $(2.8 \%)$. Regarding to cause of trauma, traumatized cases due to fall were the highest prevalence $(58.3 \%)$ for both genders, then due to violence were (25\%), and due to road traffic accident were the lowest prevalence $(16.7 \%)$

Conclusion: Based on the study results, the prevalence of traumatized permanent incisors was seen in $7.2 \%$ of Yemeni children and frequented in boys more than girls with a ratio $2: 1$. The maxillary central incisors were the most frequently affected teeth by trauma $(86.1 \%)$ of permanent incisor teeth and fall $(58.3 \%)$ was the main cause of traumatized cases.
\end{abstract}

Keywords: Prevalence; Traumatized permanent incisors; Yemeni children

\section{Introduction}

Oro-facial trauma, the second most common cause of tooth loss, has a significant negative effect on patient's appearance and mastication. It mainly affects the children and adolescents, especially their maxillary central incisors, which are the most visible. The most common risk factors are falls, automobile/bicycle accidents, collisions, gender and age, some behavioral characteristics, physical and sporting activity. Dental trauma of the incisors and their supporting tissues, which is one of the most challenging dental emergency situations, requires immediate assessment and management due to psychological and physical reasons (Wilson S et al. 1997, Gojanur S et al. 2015, Vural UK et al. 2016).

The prevalence of traumatic dental injuries (TDIs) to anterior teeth among schoolchildren has been studied in different parts of the world by many researchers, and a wide range of variation has been found. In Asia and Africa, the prevalence of TDIs to anterior teeth among adolescents ranges from $4 \%$ to $35 \%$ and $15 \%$ to $21 \%$, respectively. In America and Europe, the prevalence varied from $15 \%$ to $23 \%$ and $23 \%$ to $35 \%$, respectively. Falls and sports were the most common causes of TDIs. TDIs were reported to be more among male children compared to female children. Upper central incisors were the most frequently affected (Gupta S et al. 2011, Ain TS et al. 2016, Chalissery VP et al. 2016).

\section{Patients and methods}

i) The sample:

This study was conducted on five hundreds Yemeni children, (250) boys and (250) girls with an age ranged from $8-12$ years. The sample was collected from pediatric dental clinics, College of Dentistry, University of Sciences \& Technology, Sana'a, Yemen through the period from February to May 2017.

ii) Examination of children:

Each child was examined to detect the traumatized permanent incisors with a disposable mouth mirrors, using gloves and gauze pads. A data collecting chart was designed for recording the necessary information's for each child including personal data as name, age and gender. For each child who displayed apparent traumatized permanent incisors, the dental history was reported in order to get the information regarding the cause related to them.

\section{Results}

This study was conducted to determine the prevalence and identify the causes of traumatized permanent incisors among Yemeni children with age ranged from 8-12 years. The sample size included 500 Yemeni children, 250 boys $(50 \%)$ and 250 girls $(50 \%)$ respectively. 
Distribution of children with traumatized cases according to gender $\&$ age is summarized in table (1), which shows the following results:

In the total sample of 500 child, 36 traumatized cases ( 24 boys and 12 girls) with a prevalence of $7.2 \%$ (9.6\% in boys and $4.8 \%$ in girls). At ages (8y, 9y, 10y, 11y and 12y), the number of children was selected equally (50 child for all groups and both genders). Whereas the numbers of traumatized cases were $(2,4,4,6,8)$ in boys and $(1,2,2,3,4)$ in girls with total $(3,6,6,9,12)$ respectively.

Regarding to the gender, the prevalence of traumatized cases was found in boys $(9.6 \%)$ more than girls $(4.8 \%)$ with a ratio of $2: 1$ However regarding to the age, the prevalence of traumatized cases was less in number at age of 8 year (3\%) and more in number at age of 12 year $(12 \%)$.

Table 1: Distribution of Children with Traumatized Cases According to Gender \& Age

\begin{tabular}{|c|c|c|c|c|c|c|c|}
\hline \multicolumn{2}{|c|}{$\begin{array}{l}\text { Age } \\
\text { Gender }\end{array}$} & $8 \mathrm{Y}$. & $9 \mathrm{Y}$. & $\begin{array}{l}10 \\
Y .\end{array}$ & $11 \mathrm{Y}$. & $12 \mathrm{Y}$. & Total \\
\hline \multirow{3}{*}{$\widehat{0}$} & No. of children & 50 & 50 & 50 & 50 & 50 & 250 \\
\hline & $\begin{array}{l}\text { No. of trauma- } \\
\text { tized cases }\end{array}$ & 2 & 4 & 4 & 6 & 8 & 24 \\
\hline & Percentage (\%) & $4 \%$ & $8 \%$ & $8 \%$ & $12 \%$ & $16 \%$ & $9.6 \%$ \\
\hline & $\begin{array}{l}\text { No. of Children } \\
\text { No. of trauma- }\end{array}$ & 50 & 50 & 50 & 30 & 30 & \\
\hline \multirow[t]{2}{*}{$\stackrel{n}{\vec{E}}$} & $\begin{array}{l}\text { tized cases } \\
\text { Percentage }(\%)\end{array}$ & $2 \%$ & 2 & $4 \%$ & 3 & 86 & 12 \\
\hline & No. of Children & 100 & 100 & 100 & 100 & 100 & 500 \\
\hline \multirow{2}{*}{ 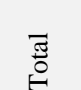 } & $\begin{array}{l}\text { No. of trauma- } \\
\text { tized cases }\end{array}$ & 3 & 6 & 6 & 9 & 12 & 36 \\
\hline & Percentage (\%) & $3 \%$ & $6 \%$ & $6 \%$ & $9 \%$ & $12 \%$ & $7.2 \%$ \\
\hline
\end{tabular}

Distribution of traumatized cases according to gender \& location of trauma is summarized in table (2), which shows the following results:

Traumatized maxillary central incisors were seen in twenty one cases of boys $(87.5 \%)$ and ten cases of girls $(83.3 \%)$ with total thirty one cases of both $(86.1 \%)$. However traumatized maxillary lateral incisors were seen in three cases of boys (12.5\%) and two cases of girls $(16.7 \%)$ with total five cases of both $(13.9 \%)$. Whereas non case was seen in mandibular central \& lateral incisors for both genders $(0 \%)$. Regarding to location of trauma, the maxillary central incisors were the highest traumatized cases $(86.1 \%)$, then the maxillary lateral incisors $(13.9 \%)$ and nontraumatized cases were seen in the mandibular incisors $(0 \%)$.

Table 2: Distribution of Traumatized Cases According to Gender \& Location of Trauma

\begin{tabular}{lllllll}
\hline $\begin{array}{l}\text { Gender } \\
\text { Location of trauma }\end{array}$ & $\begin{array}{l}\text { Boys } \\
\text { No. }\end{array}$ & $\begin{array}{l}\text { Girls } \\
\text { No. }\end{array}$ & $\%$ & $\begin{array}{l}\text { Total } \\
\text { No. }\end{array}$ & $\%$ \\
\hline $\begin{array}{l}\text { Maxillary central } \\
\text { incisors }\end{array}$ & 21 & $87.5 \%$ & 10 & $83.3 \%$ & 31 & $86.1 \%$ \\
$\begin{array}{l}\text { Maxillary lateral } \\
\text { incisors }\end{array}$ & 3 & $12.5 \%$ & 2 & $16.7 \%$ & 5 & $13.9 \%$ \\
$\begin{array}{l}\text { Mandibular central } \\
\text { incisors }\end{array}$ & 0 & $0 \%$ & 0 & $0 \%$ & 0 & $0 \%$ \\
$\begin{array}{l}\text { Mandibular lateral } \\
\text { incisors }\end{array}$ & 0 & $0 \%$ & 0 & $0 \%$ & 0 & $0 \%$ \\
Total & 24 & $100 \%$ & 12 & $100 \%$ & 36 & $100 \%$ \\
\hline
\end{tabular}

Distribution of traumatized cases according to gender \& type of trauma is summarized in table (3), which shows the following results:

Treated dental fracture was seen in six cases of boys (25\%) and five cases of girls $(41.7 \%)$ with total eleven cases of both $(30.6 \%)$, Figure (1).Whereas untreated dental fracture was seen in fifteen cases of boys $(62.5 \%)$ and six cases of girls $(50 \%)$ with total twenty one cases of both (58.3\%), Figure(2).Due to trauma, missing tooth was showed in two cases of boys $(8.3 \%)$ and one case of girls $(8.3 \%)$ with total three cases of both $(8.3 \%)$, Figure (3).Whereas excluded tooth was showed in one case of boys $(4.2 \%)$ and non case of girls $(0 \%)$ with total one case of both $(2.8$

$\%$ ), Figure(4).Regarding to type of trauma, untreated dental fracture was the highest prevalence $(58.3 \%)$ of all traumatized cases for both genders and excluded tooth was the lowest prevalence $(2.8 \%)$.

Table 3: Distribution of Traumatized Cases According to Gender \& Type of Trauma

\begin{tabular}{lllllll}
$\begin{array}{l}\text { Gender } \\
\text { Type of trauma }\end{array}$ & $\begin{array}{l}\text { Boys } \\
\text { No. }\end{array}$ & $\%$ & $\begin{array}{l}\text { Girls } \\
\text { No. }\end{array}$ & $\%$ & $\begin{array}{l}\text { Total } \\
\text { No. }\end{array}$ & $\%$ \\
\hline $\begin{array}{l}\text { Treated dental frac- } \\
\text { ture }\end{array}$ & 6 & $25 \%$ & 5 & $41.7 \%$ & 11 & $30.6 \%$ \\
$\begin{array}{l}\text { Untreated dental } \\
\text { fracture }\end{array}$ & 15 & $62.5 \%$ & 6 & $50 \%$ & 21 & $58.3 \%$ \\
$\begin{array}{l}\text { Missing tooth due to } \\
\text { trauma }\end{array}$ & 2 & $8.3 \%$ & 1 & $8.3 \%$ & 3 & $8.3 \%$ \\
$\begin{array}{l}\text { Excluded tooth due to } \\
\text { trauma }\end{array}$ & 1 & $4.2 \%$ & 0 & $0 \%$ & 1 & $2.8 \%$ \\
Total & 24 & $100 \%$ & 12 & $100 \%$ & 36 & $100 \%$ \\
\hline
\end{tabular}

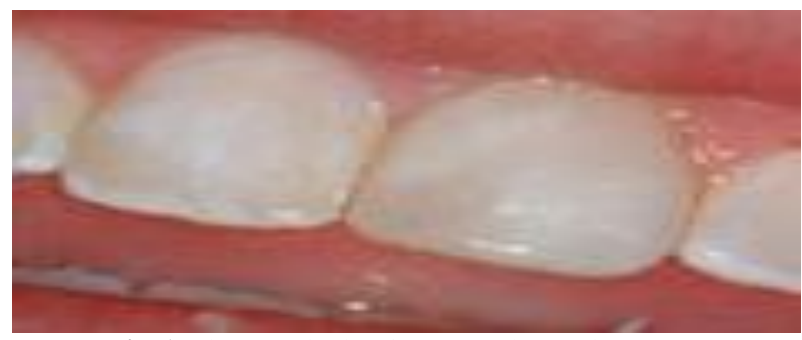

Fig. 1: Photograph Showing Treated Dental Fracture.

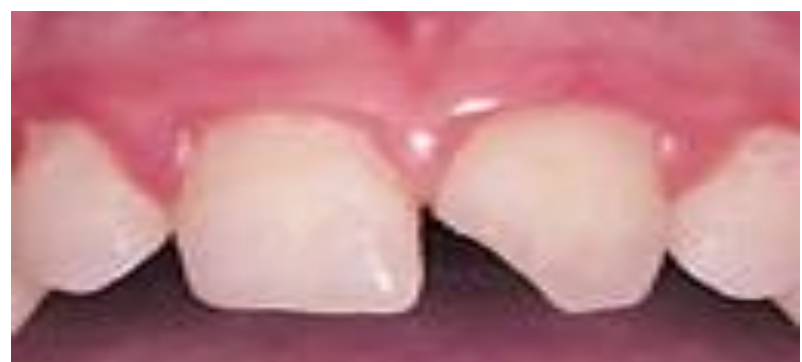

Fig. 2: Photograph Showing Untreated Dental Fracture.

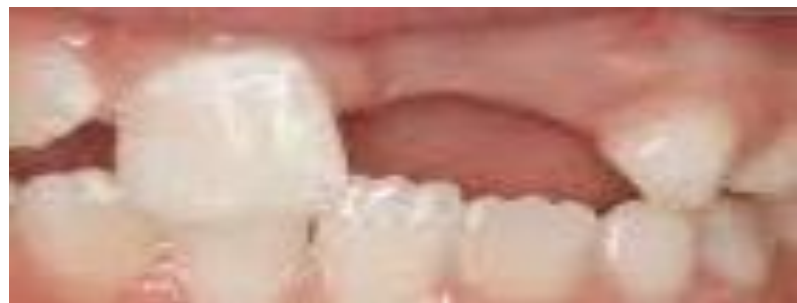

Fig. 3: Photograph Showing Missing Tooth Due to Trauma.

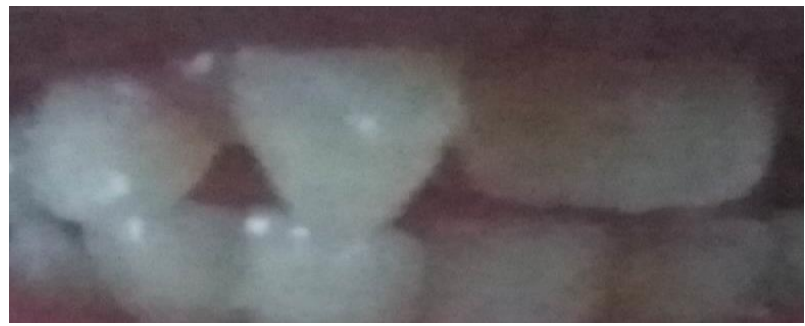

Fig. 4: Photograph Showing Excluded Tooth Due to Trauma.

Distribution of traumatized cases according to gender \& cause of trauma is summarized in table (4), which shows the following results:

Due to fall, traumatized cases were observed in fourteen cases of boys $(58.3 \%)$ and six cases of girls $(50 \%)$ with total twenty one cases of both $(58.3 \%)$. Due to violence, traumatized cases were observed in six cases of boys $(25 \%)$ and four cases of girls $(33.3 \%)$ with total nine cases of both $(25 \%)$. Due to road traffic accident, traumatized cases were observed in four cases of boys $(16.7 \%)$ and two cases of girls $(16.7 \%)$ with total six cases of both $(16.7 \%)$. Regarding to cause of trauma, traumatized cases due to 
fall were the highest prevalence $(58.3 \%)$ for both genders, then due to violence were $(25 \%)$, and due to road traffic accident were the lowest prevalence $(16.7 \%)$.

Table 4: Distribution of Traumatized Cases According to Gender \& Cause of Trauma

\begin{tabular}{lllllll}
\hline Gender & Boys & \multicolumn{3}{c}{ Girls } & \multicolumn{3}{c}{ Total } \\
Cause of trauma & No. & $\%$ & No. & $\%$ & No. & $\%$ \\
\hline Fall & 14 & $58.3 \%$ & 6 & $50 \%$ & 21 & $58.3 \%$ \\
Violence & 6 & $25 \%$ & 4 & $33.3 \%$ & 9 & $25 \%$ \\
Road traffic accident & 4 & $16.7 \%$ & 2 & $16.7 \%$ & 6 & $16.7 \%$ \\
Total & 24 & $100 \%$ & 12 & $100 \%$ & 36 & $100 \%$ \\
\hline
\end{tabular}

\section{Discussion}

In the present study, the prevalence of traumatized cases was $7.2 \%$ and this is in agreement with a previous studies (Zerman $\mathrm{N}$ and Carvalleri G 1996 in Italy, Hegde R and Agrawal G 2017 in India) who reported a prevalence of 7.3\%. Other studies (Sanchez A and Garcia-Godoy F 1990 in Mexico, Marcenes W et al. 2001 in Brazil, Marcenes W and Murray S 2002 in London, Malikaew P et al 2006 in Thailand, Krishna MA et al. 2014 in India) who reported a higher prevalence of $38 \%, 58.6 \%, 43.8 \%, 35 \%$ and $9.7 \%$ respectively. On the other hand, other studies (Baghdady VS et al. 1981 in Sudan, Alonge O et al. 2001 in Texas, Nick-Hussein NN 2001 in Malaysia, Gojanur S et al. 2015 in India) who reported a lower prevalence of $5.1 \%, 2.4 \%, 4.1 \%$ and $2.7 \%$ respectively. This difference may be due to difference in the circumstances time and conditions of the studies, ethnic reasons, economic traditions and levels of education from country to another.

In this study, there was a gender predilection of traumatized cases that indicated to a higher prevalence in boys $(9.6 \%)$ than girls $(4.8 \%)$ with a ratio $2: 1$. It may be due to the higher activities of boys than girls and their presence outside houses for sports. This finding confirmed the results of a previous studies (Scandiuzzi FS et al. 2013, Gojanur S et al. 2015, Hegde R and Agrawal G 2017). In both genders, the prevalence of traumatized cases was increased with an increase of age and more evidence at age 12 years. It may be due to the child at this age is more aware towards hobbies of active sporting during this period. This finding is in agreement with a previous studies (Malikaew P et al. 2006, Hegde R and Agrawal G 2017).

Regarding to location of trauma, the maxillary central incisors in both genders were the most frequently affected teeth by trauma $(86.1 \%)$ of permanent incisor teeth. It may be due to their anatomical vulnerable position, possibly inadequate lip coverage and they are the first maxillary permanent incisor teeth to erupt anatomically. These findings are in agreement with a previous studies (Artun $\mathrm{J}$ et al. 2005, Gopinath L and Haziani, I 2008, Scandiuzzi FS et al. 2013, Krishna MA et al. 2014). However regarding to type of trauma, the most common type of traumatized cases in both genders was untreated dental fracture that include enamel and dentine. This finding is in agreement with a previous studies (Baldava $\mathrm{P}$ and Anup N 2007, Khan NA et al. 2008).

Regarding to cause of trauma, the main cause of traumatized cases in both genders was fall $(58.3 \%)$.This finding is in agreement with a previous studies (Tapias MA et al. 2003, Zuhl K et al. 2005, Gojanur S et al. 2015, Hegde R and Agrawal G 2017) who reported that the main cause of traumatized cases was fall because the child at age ranged from $8-12$ years is more active at playing to satisfy his/her desires in games without incurring the responsibility of consequences that may lead to fracture of anterior teeth. Violence was the second cause of traumatized cases $(25 \%)$ and this finding is in disagreement with a previous study (Marcenes $\mathrm{W}$ et al. 1999) who reported that violence was the main cause of traumatic dental injuries. Road traffic accident was the third cause of traumatized cases $(16.7 \%)$ and this finding is in disagreement with a previous studies (Marcenes W et al. 2001, Nicolau B et al. 2001) who reported that road traffic accident was the main cause of traumatic dental injuries. This differences may be due to difference in the circumstances time and conditions of the studies, eth- nic reasons, economic traditions and levels of education from country to another.

\section{Conclusion}

According to the results of this study, the prevalence of traumatized permanent incisors was seen in $7.2 \%$ of Yemeni children and frequented in boys more than girls with a ratio $2: 1$. The maxillary central incisors were the most frequently affected teeth by trauma $(86.1 \%)$ of permanent incisor teeth and fall $(58.3 \%)$ was the main cause of traumatized cases.

\section{Acknowledgement}

I sincerely thank my colleagues and workers in the dental clinics at college of dentistry who supported during the study.

\section{References}

[1] Wilson S, Smith GA, Preisch J and Casamassimo PS (1997). Epidemiology of dental trauma treated in an urban pediatric emergency department. Pediatr Emerg Care ;13(1):12-15 https://doi.org/10.1097/00006565-199702000-00004.

[2] Gojanur S, Yeluri R and Munshi AK (2015). Prevalence and etiology of traumatic injuries to the anterior teeth among 5 to 8 years old school children in Mathura City, India: An epidemiological study. Int J Clin Pediatr Dent; 8 (3):172- 175. https://doi.org/10.5005/jpjournals-10005-1308

[3] Vural UK, Kiremitci A, and Gokalp S (2016). Etiologic factors and clinical evaluation of restored fractured anterior teeth: an observational study. J Istanb Univ Fac Dent.; 50(3):38-45.

[4] Gupta S, Kumar-Jindal S, Bansal M and Singla A (2011). Prevalence of Traumatic dental injuries and role of incisal overjet and inadequate lip coverage as risk factors among 4-15 years old government school children in Baddi-Barotiwala Area, Himachal Pradesh, India. Med Oral Patol Oral Cir Bucal. ;16(7): e960-5 https://doi.org/10.4317/medoral.17265.

[5] Ain TS, Telgi RL, Sultan S, Tangade P, Telgi CR, Tirth A, Pal SK, Gowhar O and Tandon V (2016). Prevalence of Traumatic Dental Injuries to Anterior Teeth of 12-Year-Old School Children in Kashmir, India Arch Trauma Res. 5(1): e24596. https://doi.org/10.5812/atr.24596.

[6] Chalissery VP, Marwah N, Jafer M, Chalisserry EP, Bhatt T, and Anil S (2016). Prevalence of anterior dental trauma and its associated factors among children aged 3-5 years in Jaipur City, India - A cross sectional study. J Int Soc Prev Community Dent; 6(Suppl 1): S35-S40. https://doi.org/10.4103/2231-0762.181165.

[7] Zerman $\mathrm{N}$ and Carvalleri G (1993). Traumatic injuries to permanent incisors. Endod Dent Traumatol; 9:61-66. https://doi.org/10.1111/j.1600-9657.1993.tb00661.x.

[8] Hegde R and Agrawal G (2017). Prevalence of Traumatic Dental Injuries to the Permanent Anterior Teeth among 9- to 14-year-old Schoolchildren of Navi Mumbai (Kharghar-Belapur Region), India. Int J Clin Pediatr Dent; 10(2):177-182 https://doi.org/10.5005/jpjournals-10005-1430.

[9] Sanchez A Sanchez A and Garcia-Godoy F (1990). Traumatic dental injuries in 3 to 13-year-old boys in Monterrey, Mexico. Endodontics and Dental traumatology; 6:63-65. https://doi.org/10.1111/j.1600-9657.1990.tb00392.x.

[10] Marcenes W, Zabot N and Traebert J (2001). Socioeconomic correlates of traumatic injuries to the permanent incisors in schoolchildren aged 12 year in Blumenau, Brazil. Dental Traumatology; 17:222-226. https://doi.org/10.1034/j.1600-9657.2001.170507.x.

[11] Marcenes W and Murray S. (2002). Changes in the prevalence and treatment need for traumatic dental injuries among 14-year-old children in Newham, London: a deprived area. Community Dental Health; 19:104-108.

[12] Malikaew P, Watt RG and Sheiham A (2006). Prevalence and factors associated with traumatic dental injuries (TDI) to anterior teeth of 11-13-year-old Thai children. Community Dental Health; 23(4): 222-227.

[13] Krishna MA, Pramila M and Ranganath S (2014). Prevalence and Associated Factors of Traumatic Dental Injuries Among 5- to 16year-old Schoolchildren in Bangalore City, India. Oral Health Prev Dent; 12 (1):37-43. 
[14] Baghdady VS, Ghose LJ and Enke H (1981). Traumatic anterior teeth in Iraqi and Sudanese children- a comparative study. J Dent Res; 60:677-680. https://doi.org/10.1177/00220345810600030201.

[15] Alonge O, Narendran S and Williamson D (2011). Prevalence of fractured incisal teeth among children in Harris country, Texas. Dental Traumatology; 17: 214-219. https://doi.org/10.1034/j.16009657.2001.170506.X.

[16] Nick-Hussein NN (2001). Traumatic injuries to anterior teeth among school children in Malaysia. Dental Traumatol; 17:149-152. https://doi.org/10.1034/j.1600-9657.2001.170402.x.

[17] Scandiuzzi FS, De Souza FFJ, Tavares PE, Dutra MR and De Jesus SA (2013). Prevalence of Traumatic Dental Injuries and Associated Factors Among Brazilian Schoolchildren. Oral Health Prev Dent; 11(1):31-8.

[18] Artun J, Behbehain F, Al-Jame B and Kerosuo H (2005). Incisor trauma in an adolescent Arab populations: Prevalence, severity, and occlusal risk factors. Am J Orthod Dentofacial Orthop; 128: 347 352. https://doi.org/10.1016/j.ajodo.2004.06.032.

[19] Gopinath L and Haziani, I (2008). Predisposing Factors and Prevalence of Fractured Anterior Teeth Among 12 And 16 Years Old School Malaysian Children. Journal of Clinical Pediatric Dentistry; 33(1):39-42. https://doi.org/10.17796/jcpd.33.1.00m21005747r3168.

[20] Baldava P and Anup N (2007): Baldava P and Anup N (2007). Risk factors for traumatic dental injuries in an adolescent male population in India. The Journal of Contemporary Dental Practice; 8 (6): $1-10$.

[21] Khan NA, Quazi HS, Maxood A and Abbas I (2008). Traumatic injuries of the permanent maxillary incisors at dental department, Pakistan Institute of medical sciences, Islamabad: a retrospective study. Dental journal ayub medical college, Abbottabad; 20(3):8487.

[22] Tapias MA, Jimenez-Gracia R, Lamas F, and Gil AA (2003). Prevalence of traumatic crown fractures to permanent incisors in a childhood population, Mostoles, Spain. Dent. Traumatol; 19:119. 122. https://doi.org/10.1034/j.1600-9657.2003.00141.x.

[23] Zuhl K, Semra O and Huseyin K (2005). Traumatic injuries of the permanent incisors in children in southern Turkey: a retrospective study. Dental Traumatology; 21(1): 20-25. https://doi.org/10.1111/j.1600-9657.2004.00265.x.

[24] Marcenes W, Beiruti N, Tayfour D and Issa S (1999). Epidemiology of traumatic injuries to the permanent incisors of 9-12-year-old school children in Damascus, Syria. Endod Dent Traumatol; 15:117-123. https://doi.org/10.1111/j.1600-9657.1999.tb00767.x.

[25] Nicolau B, Marcenes W and Sheiham A. (2001). Prevalence, causes, and correlates of traumatic dental injuries among 13-year-old in Brazil. Dental Traumatol; 17:213-217. https://doi.org/10.1034/j.1600-9657.2001.170505.x. 